\title{
Карьерный сценарий чиновника Духовного ведомства во второй половине XIX - начале XX вв. (на примере секретарей Воронежской духовной консистории)
}

\author{
М.С. Кременева \\ Белгородский государственный национальный исследовательский университет, \\ Россия, 308015, г. Белгород, ул. Победы, 85 \\ E-mail: kremeneva.m@yandex.ru
}

\begin{abstract}
Аннотация. В данном исследовании анализируются сходства и различия в карьере пяти чиновников, которые во второй половине XIX - начале XX вв. занимали должность секретаря в Воронежской духовной консистории. Научная работа проводилась в русле антропологического подхода с использованием сравнительно-исторического и просопографического методов. Главными критериями для сопоставления карьерного пути выступили образование, первое и последнее место службы, а также место, которое предшествовало занятию рассматриваемой должности, чин в должности консисторского секретаря и награды, полученные за время служебной деятельности. Результатом проведённого исследования стала реконструкция карьерного сценария секретаря Воронежской духовной консистории.
\end{abstract}

Ключевые слова: духовная консистория, Воронежская епархия, чиновничество, секретарь консистории, карьерный сценарий.

Для цитирования: Кременева М.С. 2021. Карьерный сценарий чиновника Духовного ведомства во второй половине XIX - начале XX вв. (на примере секретарей Воронежской духовной консистории). Via in tempore. История. Политология, 48 (1): 159-166. DOI: $10.52575 / 2687-0967-2021-48-1-159-166$.

\section{The career scenario of an official of the Ecclesiastical Department in the second half of the 19th - early 20th centuries (on the example of the secretaries of the Voronezh ecclesiastical consistory)}

\author{
Marina S. Kremeneva \\ Belgorod National Research University, \\ 85 Pobeda St., Belgorod, 308015, Russia \\ E-mail: kremeneva.m@yandex.ru
}

\begin{abstract}
This study investigates similarities in the careers for officials of Ecclesiastical Department. The method we applied was a prosopography and comparison of the career paths of five secretaries of Ecclesiastical consistories. The officials we selected were Consistorial secretaries in the Voronezh dioceses in the second half of the 19th century and the beginning of the 20th century. We expected to find similar points in education, first and last place of service, additional duties as a secretary, rank and awards. The results obtained show that clerks of an ecclesiastical Consistory usually had graduated from an theological seminary or theological academy. After that, the young man worked for several years in the field of office work. It is interesting to note that all the officials in question served in St. Petersburg, in the office of the Chief Prosecutor of the Holy Synod at different times of your life. The study provides strong evidence that service as an official of the spiritual Department had its own unique features in the Russian Empire.
\end{abstract}


Keywords: ecclesiastical consistory, Voronezh diocese, bureaucracy, consistorial secretary, career scenario.

For citation: Kremeneva M.S. 2021. The career scenario of an official of the Ecclesiastical Department in the second half of the 19th - early 20th centuries (on the example of the secretaries of the Voronezh ecclesiastical consistory). Via in tempore. History and political science, 48 (1): 159-166 (in Russian). DOI: $10.52575 / 2687-0967-2021-48-1-159-166$.

В последнее десятилетие в исследованиях социально-гуманитарной тематики всё чаще стало фигурировать такое понятие, как «жизненный сценарий». Преимущественно оно используется социологами и психологами (реже философами и культурологами), которые стремятся проанализировать и выявить закономерности в развитии тех или иных групп людей. В этой сфере наибольшего внимания заслуживают работы Т.Р. Вакилева [Вакилев, 2013], Л.Ю. Логуновой [Логунова, 2016], И.А. Мизиновой [Мизинова, 2013], С.Н. Петросьян [Петросьян, 2016] и З.И. Рябикиной [Петросьян, Рябикина, 2016], А.А. Чекалиной [Чекалина, 2011]. Отталкиваясь от определения «сценарности», которое фигурирует в их исследованиях, мы формулируем соответствующую дефиницию. Так, «карьерный сценарий» - это некая упорядоченность или заданность хода событий относительно профессионального становления и восхождения по служебной лестнице той или иной личности.

В частности, в нашей работе рассматривается карьерный сценарий главного чиновника в провинциальном Духовном ведомстве - секретаря Духовной консистории. Временные рамки исследования ограничены второй половиной XIX в., когда система духовных консисторий прошла более чем двадцатилетний период своей институциональной истории после введения «Устава духовных консисторий» 1841 г. и началом 1917 г., когда в результате революционных событий система регионального церковного управления претерпела качественные изменения.

Уже с начала XIX в. базовым принципом в организации гражданской службы (после того, как были учреждены министерства) стал принцип единоначалия как учреждения [Шатохин, 2006, с. 56]. Духовная консистория была поставлена под контроль светских властей [Скутнев, Скутнева, 2017, с. 88]. Так, её канцелярия состояла исключительно из светских чиновников [Курилкин, 2009, с. 120]. Её возглавлял секретарь, назначаемый в должность по предложению обер-прокурора Святейшего Синода [Фёдоров, 2003, с. 20]. Консисторский секретарь находился в двойном подчинении: сотрудничал с епархиальным архиереем, но в то же время в первую очередь подчинялся синодальному обер-прокурору [Лескин, 2017, с. 192]. Так, он осуществлял общий надзор за канцелярией, а также следил за правильностью ведения делопроизводства [Комиссаров, 2012, с. 155]. Как отмечает исследователь Э.В. Фролова, по сравнению с членами присутствия, секретарь обладал намного большим влиянием на деятельность консистории как органа епархиального управления [Фролова, 2015, с. 192].

Исследование важных вех в профессиональной жизни и деятельности консисторских секретарей проводилось нами в русле антропологического подхода. Ведущими в этой работе являлись компаративный и историко-биографический методы, а также метод просопографии. Главным источником информации выступили формулярные списки секретарей, служивших в канцелярии Воронежской духовной консистории. Стоит отметить, что в целом такие послужные списки содержат в себе большой объём информации о чиновнике, включая его социально-демографические и биографические данные, информацию о трудовой деятельности и служебные характеристики [Башкова, 2017, с. 3].

Так, анализируя и сравнивая вехи продвижения по карьерной лестнице чиновников Духовного ведомства, которые отразились в послужных списках, нами были обнаружены тождественные маркеры в их профессиональной мобильности. 
В фондах 796 (Канцелярия Синода) и 797 (Канцелярия обер-прокурора Синода) Государственного исторического архива (РГИА) нами были отобраны для сопоставления послужные списки следующих консисторских секретарей, занимавших эту должность в пределах Воронежской епархии в рассматриваемый период (расположены в хронологической последовательности пребывания в должности):

- Зеленский Михаил Иванович;

- Касаткин Александр Николаевич;

- Невоструев Александр Николаевич;

- Правдин Александр Матвеевич;

- Беллавин Пётр Павлович.

В соответствии с информацией, нашедшей своё отражение в формулярах, мы определили следующие критерии для сравнения продвижения по службе:

а) образование;

б) первое место службы;

в) место службы, предшествовавшее занятию должности консисторского секретаря;

г) последнее место службы;

д) прочие карьерные вехи;

е) чин в должности секретаря духовной консистории;

ж) награды за время служебной деятельности.

Зеленский Михаил Иванович обучался в Воронежской семинарии. По исключении из её среднего отделения в 1835 г. поступил на службу в Воронежскую духовную консисторию копиистом ${ }^{37}$. В 1843 г. он стал занимать должность столоначальника, но только в 1848 г. в ней был утверждён. С 1850 г. по 1853 г. с перерывом исправлял должность помощника секретаря консистории. В 1853 г. был определен помощником секретаря с поручением должности секретаря. Через полтора года стал непосредственно секретарём Воронежской духовной консистории, коим и являлся до 1869 г. $^{38}$ За это время М.И. Зеленский был повышен в чине (вступал в должность губернским секретарём, а с 1865 являлся уже надворным советником). Сразу после увольнения от должности консисторского секретаря был причислен к канцелярии обер-прокурора Святейшего Синода сверх штата. В ней в 1872 г. он окончил свою профессиональную деятельность (в чине коллежского советника).

Во время службы в должности консисторского секретаря Михаил Иванович получил бронзовую медаль на Владимирской ленте в память войны 1853-1856 гг. Служа в канцелярии обер-прокурора Святейшего Синода, в 1872 г. был пожалован кавалером ордена Святой Анны III степени ${ }^{39}$.

Стоит отметить, что также М.И. Зеленский, когда был столоначальником, привёл в порядок архивные дела. Также долгое время он совмещал свою службу в духовной консистории с должностью секретаря Воронежского епархиального попечительства о бедных духовного звания (с 1847 по 1867 гг.) ${ }^{40}$.

Касаткин Александр Николаевич окончил курс наук в Смоленской духовной семинарии в 1853 г. и сразу же по окончании поступил на службу в её Правление письмоводителем ${ }^{41}$. С 1854 г. началась его карьера в роли канцелярского чиновника. Так, через несколько месяцев после поступления на службу в канцелярию Витебского, Могилевского и Смоленского генерал-губернатора он был назначен помощником канцелярского секретаря. В 1857 г. был определён канцелярским чиновником в канцелярию обер-прокурора Л. 1 об.

${ }^{37}$ Российский государственный исторический архив (РГИА). Ф. 797. Оп. 39. Отд. 1. Ст. 1. Д. 223.

\author{
${ }^{38}$ Там же. Л. 4 об. \\ 39 Там же. Л. 6 об. \\ 40 Там же. Л. 2 об. \\ ${ }^{41}$ РГИА. Ф. 797. Оп. 48. Отд. 1. Ст. 1. Д. 140. Л. 1 об.
}


Святейшего Синода, в 1858 г. стал младшим помощником столоначальника, а перед переводом в Воронеж занимал должность столоначальника (с 1867 г.).

Так, в 1869 г. Александр Николаевич по определению Святейшего Правительствующего Синода был определён секретарём Воронежской духовной консистории ${ }^{42}$. На тот момент он имел чин надворного советника. В этой должности он прослужил 9 лет и окончил её в чине коллежского советника. Стоит отметить, что за это время А.Н. Касаткин также являлся делопроизводителем Воронежского епархиального комитета Православного миссионерского общества.

В 1878 г. был уволен от должности секретаря и одновременно причислен к канцелярии обер-прокурора Святейшего Синода сверх штата. Ровно через год его назначили исполняющим обязанности секретаря в Екатеринославскую духовную консисторию. В 1881 г. ему был присвоен чин статского советника.

Необходимо отметить, что за время своей профессиональной деятельности непосредственно в должности секретаря консистории Александра Николаевича наградили в 1870 г. орденом Святой Анны II степени. С 1867 г. А.Н. Касаткин являлся кавалером ордена Святого Станислава II степени, был удостоен бронзовой медали на Владимирской ленте в память войны $1853-1856$ гг. (1856 г.) ${ }^{43}$.

Невоструев Александр Николаевич окончил курс наук в Московской духовной академии в 1862 г. После этого он несколько лет служил преподавателем истории (русской, всеобщей и т. д.) сначала в Костромской семинарии, а потом в Костромской гимназии и Костромском Григоровском женском первого разряда училище. С 1868 г. А.Н. Невоструева определили помощником столоначальника в канцелярии оберпрокурора Святейшего Синода ${ }^{44}$. Спустя два года службы его назначили секретарём Екатеринославской духовной консистории (на этот момент он имел чин коллежского секретаря). Примечательно, что во время пребывания в Екатеринославской епархии он также являлся редактором местных Епархиальных ведомостей (на протяжении 5 лет) ${ }^{45}$. В 1879 г. был перемещён в Воронежскую духовную консисторию на должность секретаря, в которой и прослужил вплоть до своей смерти. Он скончался в 1882 г., на этот момент был в чине коллежского советника.

За время свой службы в должности секретаря духовной консистории Александр Николаевич был удостоен следующих орденов: Святого Станислава III степени и Святой Анны III степени ${ }^{46}$.

Правдин Александр Матвеевич обучался в Санкт-Петербургской духовной академии и окончил её магистрантом по историческому отделению в 1871 г., был одним из лучших студентов курса [Поликарпов, 1908, с. 2]. В том же году он (сверх штата) был причислен к канцелярии обер-прокурора Святейшего Синода, и в ней прослужил несколько лет. Затем, уже имея чин титулярного советника, в 1874 г. был назначен секретарём Саратовской духовной консистории ${ }^{47}$. В 1882 г. Александр Матвеевич был переведен на ту же должность в Воронежскую епархию, в которой впоследствии прослужил 24 года (дослужился до чина коллежского советника) [Звягинцева, 2017, с. 32]. В сентябре 1906 г. его назначили прокурором Грузино-Имеретинской синодальной конторы, но трудился А.М. Правдин там только чуть более года [К переходу из Воронежской епархии А.М. Правдина, 1906, с. 1029]. 2 декабря 1907 г. он скончался, на этот момент имел чин статского советника [Александр Матвеевич Правдин, 1908, с. 22].

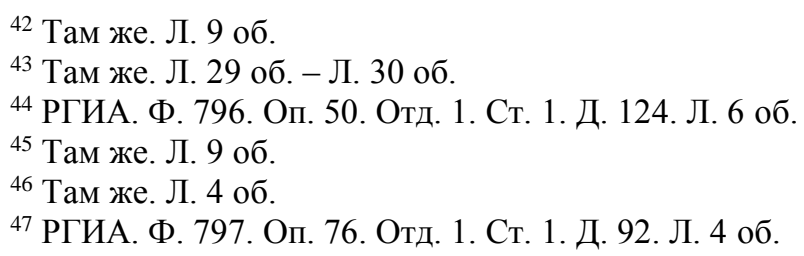


Стоит отметить, что Александр Матвеевич, пребывая в должности консисторского секретаря, в каждой епархии упорядочивал делопроизводство, исследовал её церковную историю и писал об этом статьи [Введенский, 1908, с. 39]. Также он являлся редактором официальной части местных Епархиальных ведомостей. В 1901 г. по его инициативе был основан Воронежский церковно-археологический комитет [Никольский, 1908, с. 34].

За всё время своей профессиональной деятельности в должности консисторского секретаря был удостоен следующих орденов: Святого Станислава III и II степени, Святой Анны III и II степени, Святого Владимира IV степени ${ }^{48}$.

Беллавин Пётр Павлович обучался в Казанской духовной академии и окончил её в 1895 г. со степенью кандидата богословия. В этом году он также начал карьеру как чиновник в канцелярии обер-прокурора Святейшего Синода (сверх штата). В июне-августе 1897 г. П.П. Беллавин являлся исполняющим обязанности секретаря Святейшего Синода, а в октябре того же года был назначен исполняющим должность секретаря в Екатеринбургскую духовную консисторию (на этот момент имел чин коллежского секретаря), и в 1899 г. был в должности утверждён ${ }^{49}$. После служил секретарём в Таврической духовной консистории (1902-1905 гг.), в первой экспедиции Московской духовной консистории (1905-1913 гг.). К сожалению, послужной список оканчивается 1909 г., но, согласно данным Адрес-календарей, нами выявлено, что с 1914 г. и до конца синодального периода он занимал должность консисторского секретаря в Воронежской епархии [Адрес-календарь, 1916, с. 1268]. Служа в Воронежской епархии, был коллежским советником (с 1911 г.).

Примечательно, что во время службы в различных епархиях он также являлся редактором официального отдела местных Епархиальных ведомостей, членом местного Императорского православного Палестинского общества, членом местного училищного совета.

За время своей служебной деятельности (только до 1909 г.) получил следующие ордена: Святого Станислава III степени, Святой Анны и Святого Станислава II степени. Также имел серебряную медаль на груди на двойной Владимирской и Андреевской ленте, учреждённую в память 25-летия существования церковно-приходских школ 50 .

Таким образом, проанализировав и сопоставив данные, полученные в ходе нашего исследования, мы реконструировали карьерный сценарий чиновника Духовного ведомства во второй половине XIX - начале XX вв. Отправной точкой начала карьеры было получение образования в духовном учебном заведении. На протяжении рассматриваемого периода наблюдается повышение образовательного уровня секретарей: если М.И. Зеленский имел семинарское образование, то П.П. Беллавин - ученую степень. Далее следовали несколько лет канцелярской службы, непосредственная работа в сфере делопроизводства. Преимущественно это была служба в канцелярии обер-прокурора Святейшего Синода (под данный пункт не подходит только персона М.И. Зеленского, но это отступление можно объяснить тем, что он поступил на службу в Духовную консисторию в первой половине XIX в., ещё до принятия Устава Духовных консисторий 1841 г.). Прослужившего в канцелярии несколько лет молодого чиновника, если он достойно зарекомендовал себя, обер-прокурор определял в ту или иную епархию на должность консисторского секретаря. Зачастую к этому моменту чиновник уже дослужился до чина коллежского секретаря (исключение также М.И. Зеленский - он стал им на следующий год после вступления в должность). Своеобразным продолжением профессии для секретарей консистории являлось участие в общественной жизни губернии в качестве редакторов региональных церковных периодических изданий, членов корпоративных и церковно-общественных организаций. Служебные заслуги секретарей отмечались государственными наградами, как правило, орденами Святой Анны или Святого Станислава второй или третьей степени.

\footnotetext{
${ }^{48}$ Там же. Л. 3 об.

49 РГИА. Ф. 796. ОП. 436. Д. 567. Л. 2 об.

${ }^{50}$ Там же. Л. 1 об.
} 


\section{Список литературы}

1. Адрес-календарь. Общая роспись начальствующих и прочих должностных лиц по всем управлениям в Российской империи на 1916 год. Часть I. 1916. СПб, Сенатская типография, 1526.

2. Александр Матвеевич Правдин. 1908. Воронежские епархиальные ведомости. Неофициальная часть, 1: 22.

3. Башкова И.С. 2017. Формулярный список как форма учёта служащих канцелярии Таврического губернатора в первой половине XIX в. Научный вестник Крыма, 4 (9): 1-6.

4. Вакилев Т.Р. 2013. Социальный и имущественный портреты местного чиновничества во второй половине XIX в. (по данным формулярных списков Пензенской губернии). Теория и практика общественного развития, 11: 310-313.

5. Введенский С.П. 1908. Памяти А.М. Правдина. Воронежская старина, 7: 39-40.

6. Звягинцева М.С. 2017. Секретарь Воронежской духовной консистории А.М. Правдин: историк и канцелярский чиновник. В кн.: Живая память - 2017: сборник научных трудов открытой конференции начинающих ученых и исследователей «Живая память - 2017» (с. Верхопенье, 5 мая 2017 г.). Белгород, ООО «Эпицентр»: 31-34.

7. К переходу из Воронежской епархии А.М. Правдина. 1906. Воронежские епархиальные ведомости. Неофициальная часть, 23: 1029-1034.

8. Комиссаров П.А. 2012. Кадровый состав Костромской духовной консистории во второй половине XIX - начале XX века. Вестник КГУ им. Н.А. Некрасова, 5: 167-170.

9. Курилкин И.Б. 2009. Структура епархиальных органов делопроизводства во второй половине XIX - начале XX века (на примере Оренбургской епархии). Вестник Челябинского государственного университета. Серия История, 41 (179): 119-122.

10. Лескин Д.Ю. 2017. Духовные консистории как явление самобытности отечественного государства и права: исторический аспект. В кн.: Перспективы государственно-правового развития в России в XXI веке: Сборник материалов Всероссийской научно-теоретической конференции курсантов и слушателей вузов МВД России, студентов гуманитарных вузов, адъюнктов, аспирантов и соискателей (Ростов-на-Дону, 19 апреля 2017 г.). Ростов-на-Дону, Ростовский юридический институт Министерства внутренних дел Российской Федерации: 190-195.

11. Логунова Л.Ю. 2016. Биографический метод в исследовании личности: методология и архитектоника. Вестник КомГУ. Серия: Политические, социологические и экономические науки, 1: $17-23$.

12. Мизинова И.А. 2013. Жизненный сценарий личности: основные подходы к рассмотрению. Известия Саратовского университета. Новая серия. Серия: Философия. Психология. Педагогика, 14: 59-64.

13. Никольский П.В. 1908. Памяти А.М. Правдина. Воронежская старина, 7: 33-38.

14. Петросьян С.Н. 2016. Жизненный сценарий как бытийное пространство личности. Гуманизация образования, 2: 51-59.

15. Петросьян С.Н., Рябикина 3.И. 2016. Современные подходы к проблеме жизненного сценария личности как социально-психологического феномена. Вестник АГУ, 3 (183): 123-135.

16. Поликарпов Н.И. 1908. Александр Матвеевич Правдин (2 декабря 1907 года). Биографический очерк. Воронежская старина, 7: 1-32.

17. Скутнев А.В., Скутнева С.В. 2017. Правовые основы формирования, организационная структура и деятельность духовных консисторий в XIX веке. Вестник гуманитарного образования, 6: 87-91.

18. Фёдоров В.А. 2003. Русская Православная церковь и государство. Синодальный период. 1700-1917. М, Русская панорама, 480.

19. Фролова Э.В. 2015. Статус секретаря духовной консистории в системе епархиального управления РПЦ синодального периода. Исторические, философские, политические, юридические науки, культурология и искусствоведение. Вопросы теории и практики, 6 (56): 191-195.

20. Чекалина А.А. 2011. Профессиональные события в жизненных сценариях женщинучителей. Вестник Московского городского педагогического университета. Серия: педагогика и психология, 4 (18): 35-44.

21. Шатохин И.Т. 2006. Особенности и структура государственной службы Российской империи во второй половине XIX века. Современные наукоёмкие технологии, 1: С. 56-59. 


\section{References}

1. Adres-kalendar'. Obshhaja rospis' nachal'stvujushhih i prochih dolzhnostnyh lic po vsem upravlenijam v Rossijskoj imperii na 1916 god. Chast' I. 1916 [Calendar address. General list of superiors and other officials in all departments in the Russian Empire for 1916. Part I]. SPb, Senatskaja tipografija, 1526 (in Russian).

2. Aleksandr Matveevich Pravdin. 1908 [Aleksander Matveevich Pravdin]. Voronezhskie eparhial'nye vedomosti. Neoficial'naja chast', 1: 22 (in Russian).

3. Bashkova I.S. 2017. Formuljarnyj spisok kak forma uchjota sluzhashhih kanceljarii Tavricheskogo gubernatora $\mathrm{v}$ pervoj polovine XIX $\mathrm{v}$. [The official list as the form of the accounting of employees of office of the Taurian governor in the first half of the 19th century]. Nauchnyj vestnik Kryma, 4 (9): 1-6 (in Russian).

4. Vakilev T.R. 2013. Social'nyj i imushhestvennyj portrety mestnogo chinovnichestva vo vtoroj polovine XIX v. (po dannym formuljarnyh spiskov Penzenskoj gubernii) [Social and material images of the local officials in the second half of the 19 th century (case study of the service records of the Penza province)]. Teorija i praktika obshhestvennogo razvitija, 11: 310-313 (in Russian).

5. Vvedenskij S.P. 1908. Pamjati A.M. Pravdina [For the memory of A.M. Pravdin]. Voronezhskaja starina, 7: 39-40 (in Russian).

6. Zvjaginceva M.S. 2017. Sekretar' Voronezhskoj duhovnoj konsistorii A.M. Pravdin: istorik i kanceljarskij chinovnik. V kn.: Zhivaja pamjat' - 2017: sbornik nauchnyh trudov otkrytoj konferencii nachinajushhih uchenyh i issledovatelej «Zhivaja pamjat' - 2017» (s. Verhopen'e, 5 maja 2017 g.) [Secretary of the Voronezh Spiritual Consistory A.M. Pravdin: Historian and Clerical Official. In the book: Living Memory - 2017: collection of scientific papers of the open conference of novice scientists and researchers «Living Memory - 2017» (Verkhopenye village, May 5, 2017)]. Belgorod, OOO «Jepicentr»: 31-34 (in Russian).

7. K perehodu iz Voronezhskoj eparhii A.M. Pravdina. 1906 [To the transition from the Voronezh diocese Pravdin A.M.]. Voronezhskie eparhial'nye vedomosti. Neoficial'naja chast', 23: 1029-1034 (in Russian).

8. Komissarov P.A. 2012. Kadrovyj sostav Kostromskoj duhovnoj konsistorii vo vtoroj polovine XIX - nachale XX veka [Staff composition of Kostroma spiritual consistory in the second half of the $19^{\text {th }}$ - early 20th centuries]. Vestnik KGU im. N.A. Nekrasova, 5: 167-170 (in Russian).

9. Kurilkin I.B. 2009. Struktura eparhial'nyh organov deloproizvodstva vo vtoroj polovine XIX nachale XX veka (na primere Orenburgskoj eparhii) [The structure of diocesan office-work bodies in the second half of the 19th - early 20th centuries (on the example of the Orenburg diocese)]. Vestnik Cheljabinskogo gosudarstvennogo universiteta. Serija Istorija, 41 (179): 119-122 (in Russian).

10. Leskin D.Ju. 2017. Duhovnye konsistorii kak javlenie samobytnosti otechestvennogo gosudarstva i prava: istoricheskij aspekt. V kn.: Perspektivy gosudarstvenno-pravovogo razvitija v Rossii v XXI veke: Sbornik materialov Vserossijskoj nauchno-teoreticheskoj konferencii kursantov i slushatelej vuzov MVD Rossii, studentov gumanitarnyh vuzov, adjunktov, aspirantov i soiskatelej (Rostov-na-Donu, 19 aprelja 2017 g.) [Spiritual consistories as a phenomenon of the originality of the national state and law: a historical aspect. In the book: Prospects of state and legal development in Russia in the XXI century: Collection of materials of the All-Russian scientific and theoretical conference of cadets and listeners of universities of the Ministry of Internal Affairs of Russia, students of humanitarian universities, adjuncts, graduate students and applicants (Rostov-on-Don, April 19, 2017)]. Rostov-na-Donu, Rostovskij juridicheskij institut Ministerstva vnutrennih del Rossijskoj Federacii: 190-195 (in Russian).

11. Logunova L.Ju. 2016. Biograficheskij metod v issledovanii lichnosti: metodologija i arhitektonika [Biographical method in the study of personality: methodology and architectonics]. Vestnik KomGU. Serija: Politicheskie, sociologicheskie i jekonomicheskie nauki, 1: 17-23 (in Russian).

12. Mizinova I.A. 2013. Zhiznennyj scenarij lichnosti: osnovnye podhody k rassmotreniju [The vital script of the personality: the basic approaches to consideration]. Izvestija Saratovskogo universiteta. Novaja serija. Serija: Filosofija. Psihologija. Pedagogika, 14: 59-64 (in Russian).

13. Nikol'skij P.V. 1908. Pamjati A.M. Pravdina [For the memory of A.M. Pravdin]. Voronezhskaja starina, 7: 33-38 (in Russian).

14. Petros'jan S.N. 2016. Zhiznennyj scenarij kak bytijnoe prostranstvo lichnosti [Life script as individual's existential space]. Gumanizacija obrazovanija, 2: 51-59 (in Russian). 
15. Petros'jan S.N., Rjabikina Z.I. 2016. Sovremennye podhody k probleme zhiznennogo scenarija lichnosti kak social'no-psihologicheskogo fenomena [Current approaches to the problem of personality life script as social and psychological phenomenon]. Vestnik AGU, 3 (183): 123-135 (in Russian).

16. Polikarpov N.I. 1908. Aleksandr Matveevich Pravdin (2 dekabrja 1907 goda). Biograficheskij ocherk [Alexander Matveevich Pravdin (December 2, 1907). Biographical sketch]. Voronezhskaja starina, 7: 1-32 (in Russian).

17. Skutnev A.V., Skutneva S.V. 2017. Pravovye osnovy formirovanija, organizacionnaja struktura i dejatel'nost' duhovnyh konsistorij v XIX veke [Legal bases of formation, organizational structure and activities of the spiritual consistories in the nineteenth century]. Vestnik gumanitarnogo obrazovanija, 6: 87-91.

18. Fjodorov V.A. 2003. Russkaja Pravoslavnaja cerkov' i gosudarstvo. Sinodal'nyj period. 1700-1917 [Russian Orthodox Church and State. Synodal period. 1700-1917]. M, Russkaja panorama, 480 (in Russian).

19. Frolova Je.V. 2015. Status sekretarja duhovnoj konsistorii v sisteme eparhial'nogo upravlenija RPC sinodal'nogo perioda. Istoricheskie, filosofskie, politicheskie, juridicheskie nauki, kul'turologija i iskusstvovedenie [Status of secretary of Ecclesiastical consistory in the system of diocesan administration of the Russian Orthodox Church of the synodal period]. Voprosy teorii i praktiki, 6 (56): 191-195 (in Russian).

20. Chekalina A.A. 2011. Professional'nye sobytija v zhiznennyh scenarijah zhenshhin-uchitelej. [Professional events in life scripts of women-teachers]. Vestnik Moskovskogo gorodskogo pedagogicheskogo universiteta. Serija: pedagogika i psihologija, 4 (18): 35-44 (in Russian).

21. Shatohin I.T. 2006. Osobennosti i struktura gosudarstvennoj sluzhby Rossijskoj imperii vo vtoroj polovine XIX veka [Features and structure of the civil service of the Russian Empire in the second half of the 19th century]. Sovremennye naukojomkie tehnologii, 1: S. 56-59 (in Russian).

\section{ИНФОРМАЦИЯ ОБ АВТОРЕ}

Кременева Марина Сергеевна, аспирант кафедры российской истории и документоведения Белгородского государственного национального исследовательского университета, г. Белгород, Россия

\section{INFORMATION ABOUT THE AUTHOR}

Marina S. Kremeneva, Postgraduate Student, Department of Russian History and Documentation, Belgorod State National Research University, Belgorod, Russia 